\title{
Born free: a tale of two rivers
}

\author{
Tauriq Jenkins $^{1} \cdot$ Richard Ennals $^{1} \cdot$ June Bam-Hutchison ${ }^{1}$
}

Received: 10 May 2021 / Published online: 18 January 2022

(c) The Author(s), under exclusive licence to Springer-Verlag London Ltd., part of Springer Nature 2021

The histories and cultures of indigenous peoples around the world have typically been largely neglected, as priority has been given to publishing colonial accounts. This is particularly true of the San and Khoi peoples of the Cape region of South Africa, who had successfully resisted the first Portuguese and Dutch invaders in the sixteenth and seventeenth centuries, but were then dispossessed of their lands, with successive land wars, colonial regimes and the Apartheid government until 1994. Efforts are being made to change this, with a crucial role for archives.

The San and Khoi Research Centre was founded in April 2020, in the Centre for African Studies at the University of Cape Town, with a mission to build the research foundations to enable the record to be set straight. The focus has been on creating and digitising archive materials, building a new resource for multidisciplinary research. A unique set of collections and archives has been developed, housed at the University Library at UCT, as an international resource for scholars.

On 18th April 2021, a wildfire, which started on the slopes of Huri! Oaxa (the indigenous name for Table Mountain), devastated the Jagger University Library, destroying much irreplaceable material. A detailed audit of the damage has yet to be completed. An international academic support network will need to be developed, as the implications of the losses to the archives have an impact across Africa and the Global South.

This paper was submitted for the "Born Digital" Special Issue of AI \& Society.

Richard Ennals

richard.ennals@gmail.com

Tauriq Jenkins

tauriq.jenkins@uct.ac.za

June Bam-Hutchison

june.bam-hutchison@uct.ac.za

1 San and Khoi Research Centre, Centre for African Studies, University of Cape Town, Cape Town, South Africa
Recent events have shown the current practical urgency of the ongoing threats to the San and Khoi peoples. The global technology giant Amazon has been proposing a major development at the Two Rivers Urban Park in Cape Town, as part of their plan to develop what they see as the growing African market for online retail and services. This represents a neo-colonial threat to the local economy and society. On a floodplain which has been the sacred ancestral burial site for the San and Khoi, Amazon plans to build a 12 storey headquarters building, as the anchor development in a large site which had previously been officially protected as a heritage site. There have been vigorous objections on environmental and cultural grounds, but these have been largely ignored by Amazon and the developers. Despite the fact that legal processes continue, on 20th April Amazon announced their decision to proceed with developing the Two Rivers site. It was reported that bulldozers were ready to move in from June.

On Freedom Day, 27th April 2021, marking the end of the Apartheid government and the first democratic elections, there was a March of Remembrance to the Two Rivers site. A large, dignified and peaceful event included many speeches, and provided a wealth of new material for a new digital archive. Organised by Tauriq Jenkins, speakers included the veteran Anti-Apartheid campaigner Revd Allan Boesak. There were 58,000 signatures to a petition opposing the development.

In August 2021, detailed affidavits were submitted to the High Court, documenting objections in line with legal procedures. The developers and local planning authorities chose to proceed regardless, in effect setting aside the rule of law in favour of claimed economic benefits. Bulldozers are now on site, causing irreparable damage. High Court proceedings continue.

It is not simply a matter of history. There are vital ongoing legal and cultural issues, with implications for other First Nations around the world. In the context of the current COVID pandemic, the C19 People's Coalition has brought together numerous civil society groups, including from the San and Khoi. Using the latest digital technologies, they 
have set out a constructive approach to vaccination and social policy, based on community engagement, which has been commended by the United Nations Human Rights Council and the World Health Organisation, leading to PanAfrican collaboration and engagement with the global People's Vaccine Campaign.

In South Africa since 1994, Truth and Reconciliation Commissions have provided a recognised means of moving on from long entrenched positions. As Revd Allan Boesak argued, there is now a new suitable case for treatment, addressing key issues regarding knowledge and cultural heritage, with a focus on the indigenous San and Khoi peoples.

Amazon has achieved remarkable global technology dominance, which affects many parts of the economy and society. For example, they sell a wide variety of books on Khoisan history, in hard copy and digital formats. They have made South African music globally available. Now they want to extend their operations in online retail across Africa, with major implications for traditional retail and local economic relationships.

There is a problem which is familiar to the AI \& Society community. Not all technology applications are necessarily socially appropriate. Not all knowledge is explicit. We need to take account of implicit and tacit knowledge, if we are to grasp the complexities of a situation. This poses direct challenges, for example to indigenous peoples, whose rich implicit and tacit knowledge have long been neglected, accentuating the need for archives. In the current confrontation over Two Rivers, there is a pressing need to develop and deploy archives which are "born digital". This is in line with the ongoing mission of the San and Khoi Research Unit. Michel Foucault (1972) argued that "The domain of things said is what is called the archive; the role of archaeology is to analyse that archive." In the Two Rivers case, the land is part of the archive, as is the discourse surrounding heritage and environmental issues.

In both South Africa and the UK, we increasingly recognise the case for "Decolonising History". History as taught in our schools tends to give a colonially oriented account (Bam et al. 2018). It neglects the impact, for example, of slavery, the slave trade and empire (Ennals 2007). The whole history of industrialisation over the last three centuries needs to be rewritten, as a matter of priority.
AI \& Society, since the first issue in 1987, has debated "Socially Useful Technology". The case of Two Rivers highlights this as a current challenge for Amazon. They have faced recent widespread public criticism regarding Corporate Social Responsibility, Sustainability, Ethics and Governance. Participation in a new Truth and Reconciliation Commission could offer a peaceful route to co-operative relationships with local stakeholders, and the realisation that they could be invaluable partners in rebuilding collections and archives at the University of Cape Town. There is the possibility of emerging from a current "dark" period, developing and making constructive use of "born digital" cultural assets. Both June Bam-Hutchison and Tauriq Jenkins are preparing new academic books and papers, from the San and Khoi Research Unit (e.g. eds. Muthien and Bam 2021, and subsequent volumes in the "Rethinking Africa" series).

From the ashes of the tragic fire at the University Library, flame lilies are growing.

Curmudgeon Corner Curmudgeon Corner is a short opinionated column on trends in technology, arts, science and society, commenting on issues of concern to the research community and wider society. Whilst the drive for super-human intelligence promotes potential benefits to wider society, it also raises deep concerns of existential risk, thereby highlighting the need for an ongoing conversation between technology and society. At the core of Curmudgeon concern is the question: What is it to be human in the age of the AI machine? -Editor.

\section{References}

Bam J, Nitsebaza L, Zinn A (Eds.) (2018) Whose history counts: decolonising African pre-colonial historiography. African SUN Media, Stellenbosch

Ennals R (2007) From slavery to citizenship. Wiley, Hoboken

Foucault M (1972) The archaeology of knowledge. Tavistock, London Muthien B, Bam J (Eds.) (2021) Rethinking Africa: indigenous women reinterpret South Africa's pasts. Jacana, Johannesburg

Publisher's Note Springer Nature remains neutral with regard to jurisdictional claims in published maps and institutional affiliations. 